\title{
Literary Archetypes Between Universal Myth and Historical Moment: Shelley's Frankenstein
}

\author{
Kalea Ramsey \\ Menaul School, New Mexico,USA, kalears0327@gmail.com
}

\begin{abstract}
This research uses Mary Shelley's Frankenstein as an anchor to look back and forth between the novel and the precursor texts and themes on which Shelley both draws and which she also transforms in light of the critical influences of her historical moment, straddling as it did a transition from the rationalism of the Enlightenment to the emotional, social and creative energies unleashed by Romanticism. This paper focuses on the themes of transgression, fear, isolation, damnation and redemption, and their importance in outlining the journeys of Victor Frankenstein and the monster he created, as well as other related works in history. The major comparisons in this research are that of Frankenstein with the archetypal figure of Prometheus, 'The Rime of the Ancient Mariner', and Paradise Lost. The first was directly referenced by Mary Shelley in the allusions of Walton and Victor Frankenstein, and the latter is the epigraph of the book, which appears as one of the books that shaped the Monster's education. Stemming from 'The Rime of the Ancient Mariner', the Wandering Jew and the biblical Cain and Abel story are extended archetypes, further showing traits that could be found among the Mariner, Frankenstein, the Monster, and Satan, forming an interconnected web that weaves all these characters together. Frankenstein is also known as the 'Modern Prometheus': through her writing, Mary Shelley aimed to historicize and reconceptualize universalist assumptions about the nature and relevance of archetypes in literature. By historicizing the role of Prometheus and imbuing it in Victor Frankenstein, Shelley portrayed the figure of an ambitious scientist who assumed the role of God and disregarded the law of nature. She charaterized Victor such that his traits resemble those of Prometheus, yet far from reproducing an idealized archetype, Shelley brings a Greek myth down to earth, transforming it so that it can speak to the people of her time. This paper reads Frankenstein in relation to how its context transforms the universalist archetypes on which Shelley drew to give her characters and themes literary depth and texture. Shelley inflects Victor Frankenstein and his Monster with traits associated with the archetypal figures of Prometheus, Satan, and the Ancient Mariner, simultaneously relating the resulting hybrid characters to the pressing concerns of her particular historical moment and demonstrating that universal archetypes continue to be rich sources both for the creative process and for bringing perennial themes to life for successive generations of readers.
\end{abstract}

KEYWORDS: Archetypes, Cain, Edmund Burke, Enlightenment in literature, Frankenstein, French Revolution, Mary Shelley, Prometheus, Paradise Lost, Romanticism, Satan, Samuel Taylor Coleridge, The Rime of the Ancient Mariner, Wandering Jew

\section{Introduction}

Mary Shelley's Frankenstein celebrated its 200th anniversary in 2018. Her work, and the characters of Frankenstein and his Monster, have cast an incalculable influence over popular culture for the last century, inspiring numerous novels, films, video games, and graphic art. The Monster has became one of the most well-known icons of horror. When writing her novel, Shelley imbues the Monster with, instead of total villainous intentions, an ambiguous character. He is both a victim and victimizer, which demonstrates that one of Shelley's main goals is to historicize and reconceptualize our assumptions about the nature of myths and claim that archetypes are not either/or like human beings; they are complicated, limited, capable of both good and evil. Ultimately, they are obliged to accept their limitations, recognize the impossibility of seeking transcendence from God, and realize there's no absolute redemption. Using archetypal figures such as the Ancient Mariner, Prometheus, and Satan, Shelley examines universal themes in light of the influence of her own contemporary context.

Shelley lived in the time of the French Revolution, a period characterized by radical hope and conservative fears, as is revealed in the famous debates over the Revolution. The conservatives feared change while not rejecting it, imbuing the idea of monsterism with anti-social radical motives as a warning to the people and to an ordered society. Edmund Burke, a conservative, wrote, "[t]he portentous state of France-where the Elements which compose Human Society seem all to be 
dissolved, and the world of monsters to be produced in the place of it" (Botting 1990, 22-41). Here, Burke forms a link between social radicalism and the idea of the monster. He fears the possibility of anarchy and believes that two types of monsterism, the mob and the individuals, plague society. The mob is contrary to civilization because it's ruled by passions; the individual is also contrary to civilization because he has no obligation to society: he is isolated and drawn only to himself.

Burke's quote begins with "portentous", which means 'to warn', a meaning which parallels the etymology of "monster", from "monere", which means 'to warn' in Latin. The fact that Frankenstein features a monster as its anti-hero is evidence that Shelley is referencing the symbolism of monsterism which was exploited by Burke. The idea of monsterism as uniting opposing characteristics was passed onto Shelley; after all, she characterizes Victor as monstrous in his scientific ambition and in his neglect of his creation, and the creature as monstrous in the way he takes revenge against Victor's neglect. The figure of the Monster, personified as Satan, has initially an urge for companionship and equality of treatment, but also arouses conservative fears since the Monster can disrupt the order of things. This is a message Shelley wants to communicate by the Monster character as a moral trait but also as a metaphor for her times.

\section{The Prometheus Archetype}

Mary Shelley wrote Frankenstein at a time between two major historical periods: the Enlightenment and Romanticism. The Enlightenment argued that reason is the essential aspect of life, whereas Romanticism was a movement against that way of thinking and emphasized the emotions. There is a tension between the two ideals within the novel since Frankenstein dramatizes the moral implications of the tension between reason and emotion, which is paralleled in the respective historical moments. The Enlightenment marks a period of a rise of acquisition of knowledge and radical ambition in the scientific and social realms which contrasts with the emphasis on human emotion, the sublime power of nature, and the autonomy of the individual creative impulse as valorized by Romanticism.

An essential motif of the Enlightenment is light. Frankenstein dramatically emphasizes imagery of light and darkness. When talking about his obsession with science, Victor indicates his desire to break through the line between life and death and proves to everyone what they failed to see: "Life and death appeared to me ideal bounds, which I should first break through, and pour a torrent of light into our dark world" (Shelley 1818, 54; Botting 1990). He talks in the tone of an omnipotent creator, as if imitating the biblical God: "Let there be light, and there was light" (Genesis, 1:3). Frankenstein assumes that position by comparing his influence to that of a ray of light, which brings into our knowledge what was previously obscured by ignorance. Here, the concepts of ignorance and knowledge form a binary opposition: knowledge is privileged over ignorance, light over darkness. The Enlightenment era's emphasis on light also parallels the fire motif in the Prometheus story (Shelley 1818). The light used thus symbolizes a revelation of knowledge and truth. Under the influence of both the Enlightenment and Prometheus, Shelley used the element of light and drew connections between the monster and Prometheus in multiple ways, both in literary and symbolic senses. Prometheus defied the Gods' monopoly over fire and granted this power to mankind to trigger fire; under Mary Shelley's pen, Victor's action forms a parallel to that of Prometheus's because the life Victor creates is generated through galvanism (Brunel 1995, 968-981), and the sparks of electricity share an imagistic quality with fire. The Monster's first encounter with fire was that of an ignorant infant's reaction: "One day, when I was oppressed by cold, I found a fire which had been left by some wandering beggars, and was overcome with delight at the warmth I experienced from it. In my joy I thrust my hand into the live embers, but quickly drew it out again with a cry of pain" (Shelley 1818, 120). The Monster's description of his action reveals his ignorance of the elements of human life: "overcome," "thrust," "cry of pain" reveal his ignorance, and the words suggests a humanized response of the monster archetype, as if assimilating him with the primitive human to whom Prometheus has given the fire. The Monster sees this fire for the first time and has no concept of the danger hidden inside the warmth. The immediate quality that he associates with fire is its power to warm, which connotes its the positive feature. But the very power fire has to warm carries with it the contrary power to wound. The 
paradoxical nature of fire shows that there's an immediate consequence for the treasured object that Prometheus and Victor steal. Victor has appropriated power from the gods: his creation of life through electricity is intended to parallel Prometheus's stealing of fire from the Gods. The quote showcases the Monster's experience becoming a metaphor for discovery, by which potentially uncontrollable dangers may be revealed. He went through both thrill and horror, and both pleasure and pain, which the creator himself experienced in giving birth to his creature. Thus the Monster is duplicating the experience of the creator, because he's making a primal discovery about the inseparability of pleasure and pain just as Victor was himself overjoyed by his discovery of the spark of life and yet repelled by the very life that he creates. The Monster is as if a projection of all the repressed emotions in Victor. Even though he wants to deny his kinship with the Monster, Shelley keeps offering motifs and imagery which draw out the inseparability of creator and creature. The Monster's primal scene of discovering fire symbolizes such inseparability: moral paradox, the notion that pleasure can create pain and vice versa, and that good cannot be wholly separated from evil, challenges the Enlightenment ideal of rationality and its ambition to engineer a society which is free from pain and immorality.

The Monster, though intrigued and troubled by his discovery of fire, learns to adapt to its power by closely observing its properties. We could easily trace his line of thinking and deduction: "I examined the materials of the fire, and to my joy found it to be composed of wood. I quickly collected some branches, but they were wet and would not burn. I was pained at this and sat still watching the operation of the fire." Here, he again reveals traits of his creator. The Monster is the primitive savage, duplicating Victor, the sophisticated scientist, in his action of "collecting" branches in order to succeed in building a fire, just as Victor was collecting body parts from slaughterhouses. His action is reminiscent of that of a man on the path to full truth, answers, and enlightenment. Through painstakingly figuring out an issue by himself, the Monster shows his desire to learn and grasp the truth, a desire which typifies the Enlightenment. There are two levels of truths expressed here, though: one is the empirical level - the properties of the natural, physical world, such as wet wood won't burn, and therefore fire can be put out by water. The other is the moral and philosophical level - the realization that acquiring knowledge of nature won't necessarily lead to happiness. Frankenstein's story proves that empirical facts do not straightforwardly track moral truth. The novel thus makes a powerful point about the limitations of human capacity. With all the knowledge he learned, Frankenstein ultimately does not have the power to alter the natural world or to control what he creates with his knowledge. Scientific knowledge helped him create because he understood the properties of galvanism, alchemy, and anatomy, but he doesn't have total control over the moral consequences. Similarly, the Monster enjoys the warmth of fire, yet is pained at the fact that he can't control it.

\section{Dualism}

The ambiguity and dualism at the center of the Promethean archetype recurs in Victor Frankenstein, too. Prometheus' ambiguity is portrayed through a relativizing of perspectives on his nature and achievements. Humans see Prometheus as a martyr for a moral cause, yet he is a rebel figure to Zeus. The consequence he faces as a result of this dualistic perspective is that he becomes the victim of Zeus' anger but suffers for the benefit of mankind. Similarly, Victor compares himself to both God and Satan, associating himself with two characters at opposing ends of the moral spectrum. On the one hand, he does God's work by creating a man, but on the other hand, he has the devil's motives, which are excessive pride and the desire to wield power: "All my speculations and hopes are as nothing, and like the archangel who aspired to omnipotence, I am chained in an eternal hell" (Shelley 1818, 261). The archangel is a direct allusion to Satan who stole what only God's grace could offer and who suffers the moral consequence of his ambition rather than enjoying the rival power with which he challenges God's omnipotence. While in Prometheus's case the human is the beneficiary, no one in particular in Frankenstein's story gains benefits from his suffering. However, from a meta-literary point of thinking, we, as readers, are the receivers of the cautionary moral his tale grants. As will be shown later in this paper, this meta-literary effect is similarly in play in the relationship which the Ancient Mariner shares 
with its readers. On the level of discourse between writer and readers, the Mariner was able to gain relief because of the fact that we as readers continued to listen to his story. We learn from and recognize the lessons from the Ancient Mariner's sin as well as Frankenstein's Promethean ambition to play God.

\section{Defiance of Nature}

The Promethean archetype is also reflected in Frankenstein by the themes of hubris and defiance. There are three types of defiance of nature Shelley showcased, including defiance against natural morality, human nature, and the literal natural landscape.

Victor transgressed morally by abandoning his creature and denying his responsibility as a parent. "...Breathless horror and disgust filled my heart. Unable to endure the aspect of the being I had created, I rushed out of the room and continued a long time traversing my bed-chamber" (Shelley 1818, 59) He was terrified at the sight of the Monster, and at that moment he forgot about his responsibility as parent. He chose an unnatural path by intentionally neglecting his child. His action reflects the Enlightenment ideal of rationality, the type of reason unsoftened by human sentiment. His rationality is further supported with his choice of social status over family obligations. In the same way he expresses awe in the face of the powers of nature, Victor respects human nature in society due to the individuals who had obtained esteem, reputation, the ability to elict awe, and - in Frankenstein's wildest vision — capable of doing the most Promethean thing, to create life and play the role of God. The consequence of this view is that he is denied natural companionship, thus leading to corrupting isolation. "I threw myself into the chaise that was to convey me away and indulged in the most melancholy reflections. I, who had never been surrounded by amiable companions, continually engaged in endeavoring to bestow mutual pleasure-I was now alone"(Shelley 1818, 42). Victor says this after his mother dies, and he was able to continue his education in University. Victor preferred obsessively to pursue science and neglect social relations, thus excluding himself from the community.

Victor's defiance of nature is also showcased in the sense of human nature. He views human nature as mechanistic: a human being is simply the sum of anatomical parts with additional hints of animation, demonstrated by his labor in collecting and piecing together parts of human bodies from slaughter houses. Thus, human beings are almost like mechanical objects, which could function as long as everything is correctly, scientifically, pieced together. Because he devalues moral depth in human life, Victor's only way of feeling self-complete is to acquire bits and pieces, whether it is body parts, reputation, or knowledge. He perceives knowledge as simply separate fields: he investigates separately in chemistry, biology, and galvanism. Without grasping the full picture, Victor reduces the value of human nature to the capacity simply to acquire a social reputation and denies the fact that he is one individual living with other human beings just like him. He fails to recognize that the creature has a moral life and thus natural needs. The rhetorical figure by which his mechanistic conception of human nature is conveyed is that of the doppelgänger. Victor and the Monster are doppelgängers because each symbolizes fragmentation, one psychological, one physical. The Monster yearns for psychological wholeness though physically he is an aggregate of parts. And Victor, the whole physical human person, is repelled by relations. "I thought that the fiend followed me and might expedite my remissness by murdering my companion" (Shelley 1818 , 197). In a way, Victor even anticipates the Monster's line of thoughts, contemplating vicious acts of murder and a wish to be left alone. This moment of synchronized mind shows the doubling between Victor and his creation.

Victor's controlling character is another example of his defiance of human nature, since he treats others as possessions rather than independent human beings. Such an urge began as early as the day he met Elizabeth, to whom his mother referred as a gift to him to love and care for. Victor's hubris thus denies him the chance to bridge relationships with the independent thoughts of other people. Paradoxically, however, he himself is portrayed as being controlled by the urban, social environment as if he's a prey in the face of predators. His hubristic ambition to control human nature is punished by his vulnerability in the context of the urban, social world: "Melancholy followed, but by degrees I gained a clear conception of my miseries and situation and was then 
released from my prison. For they had called me mad, and during many months, as I understood, a solitary cell had been my habituation" (Shelley 1818, 245) When Victor decides to tell the Magistrate about the creature, people think him insane and they lock him away. Society rejects him and sees him as a delirious, mad scientist, thus denying him the cooperative and social symbols of human nature, which consequently reduced him to the state of prey.

The third aspect of nature is in the literal sense-landscape. Victor's relationship to the world is binary, where he either exercises control or is controlled. In the urban world, he is a being controlled, yet he achieves existential peace in the midst of awesome natural landscapes. The fact that he seeks belonging in nature is compensation for his inability to belong to and among other human beings. The fact that Victor tends to compartmentalize the notion of human nature as a mere amalgam of parts is paralleled by the idea that the world itself is an aggregation of two separate entities, the social and natural worlds. Lacking an integrated gestalt view of the world, Victor sees his own nature, his morbid impulses of studying dead bodies alone for two years, as consistent with the inhospitable environment around him.

\section{Satan figure}

Wandering in the forest and suffering from hunger, cold, and confusion, the Monster picks up three classics, one of which is John Milton's 17th century epic poem, Paradise Lost (Holmes 2016, 49-492). Milton's purpose is to "justify the ways of God to man" (Milton 2004, 1. 26), but the most vivid and dramatic character in the poem is the Satan figure. Therefore, the Satanic character became a major influence in the Monster's path of education and in shaping his view of humanity.

The Monster had compared himself to Adam, "Like Adam, I was apparently united by no link to any other being in existence" (Shelley 1818, 154) drawing the commonality that both of them were the first creation of their kinds with no genealogy, no partners, no families to them company or to muffle their loneliness. Yet he felt more connected to Satan, "Many times I considered Satan as the fitter emblem of my condition, for often, like him, when I viewed the bliss of my protectors, the bitter gall of envy rose within me."

Possessing traits of both characters, the monster went through a transition from Adam to Satan. He draws an analogy between his predicament and Adam's and accentuates the fact that the creator created him with nothing. When the Monster sought natural affections, he was rejected: "Everywhere I see bliss, from which I alone am irrevocably excluded. I was benevolent and good; misery made me a fiend" (Shelley 1818, 114) He changed from someone who was to be born as a perfect creation, to a Monster who committed murder. His own nature became inherently evil because of his ambition to make evil his good. He said, "I had cast off all feeling, subdued all anguish, to riot in the excess of my despair. Evil thenceforth became my good. Urged thus far, I had no choice but to adapt my nature to an element which I had willingly chosen" (Shelley 1818, 273) The transition point is almost predetermined: the fact that he was born with nothing and had a natural impulse to seek what he lacks, yet was rejected, is an undertone of him developing into a Satanic character.

In the Inferno of Dante Alighieri (1935), the ninth level of Hell where Satan resides is a frozen region where traitors are damned: "With their muzzles above water, so in a like state, ere the sad, livid souls surged in this iciest of places up to where shame is expressed. Their teeth chattering away like the harshest click of storks' beaks" (Milton 2004). The image of ice is a direct opposition to God's love and grace, thus symbolizing isolation and damnation. Frankenstein utilizes the ice motif in the arctic scenes where Walton travels, Victor chases the monster, and where the Monster's life ends. Likewise, the ice motif is used in Samuel Coleridge's 'The Rime of the Ancient Mariner', at the beginning as the ship was sailing through the arctic, "The ice was here, the ice was there / The ice was all around: / It cracked and growled, and roared and howled, / Like noises in a swound!"(Coleridge 1970, 11. 59-62; Brunel 1995, 1008-1025). The Ancient Mariner archetype was adapted by Shelley in Frankenstein, Coleridge's character reflecting aspects of both Victor and the Monster. 


\section{'The Rime of the Ancient Mariner'}

The quotes referenced by Mary Shelley from 'The Ancient Mariner' first appear in the first narrative frame of Frankenstein, which is the epistolary part, among the letters written by Walton to his sister. "I am going to unexplored regions, to "the land of mist and snow," but I shall kill no albatross; therefore do not be alarmed for my safety or if I should come back to you as worn and woeful as the ancient Mariner" (Shelley 1818, 10). This quote expresses his concern over the hazardous environment. The same Arctic setting with 'The Ancient Mariner' makes the two characters seem comparable and similar, yet Walton's quote expresses a sense of confidence, consciously separating himself from the Mariner character. Walton, the natural philosopher, describes his adventure in a way that it almost seems like he is unconsciously desiring to have his humanity dwarfed by sublimity. His words showcase fascination with and excitement by the unknown, "[i]t is impossible to communicate to you a conception of the trembling sensation, half pleasurable and half fearful..." (Shelley 1818, 10). The arctic landscape minimizes human's importance and emphasize the presence of a higher power. The "trembling" indicates fear that accompanies the will to explore undiscovered realms. Instead of backing down, Walton was motivated by these sensations, almost urged to be exposed to the awesome and terrifying. By referencing the albatross, Walton appears as a foil who consciously uses the ancient mariner's character to contrast with himself. Despite that, however, the reference ironically foreshadows the curse and transgression which falls on Frankenstein, who is seeking scientific sublimity by breaking the borders of knowledge.

Walton's letters also pose a contrast with the character of the Mariner. The letters from Walton to his sister shows the family subplot, invoking trust, mutual care, and reliance. Thus, in contrast to the ancient mariner, who is divorced from family and companionship, "the land of mist and snow" for Walton brings out themes of love and tenderness; for the Mariner it generates a sense of despair and isolation. Mary Shelly sets up a contrast between Walton and the Mariner, but the contrast disappears when moving on to Victor, who shares its emotions and fate with the Mariner.

The next important reference is in the middle narrative frame, where the focus shifts to Victor's recounting his story, namely his obsession with constructing life from matter. As soon as the creature wakes up, Victor is repelled by it and flees the scene, wandering around the streets of Ingolstadt. "My heart palpitated in the sickness of fear, and I hurried on with irregular steps, not daring to look about me" (Shelley 1818, 61). This brings about his awareness of a moral conscience: he's scared to turn around to face it. The trope of turning captures the theme of transgression that arises as a result of his deeds. Continuously walking the street, Victor quotes directly from the Mariner, "Like one who, on a lonesome road, doth walk in fear and dread, and, having once turned round, walks on, and turns no more his head; because he knows a frightful fiend, doth close behind him tread-"(Coleridge 1970, 11. 446-451). Here, the previous juxtaposition of Walton and the Mariner intensifies the effects of such a direct quote from the Mariner, stressing his dire predicament. Even before creating the Monster, Victor was isolated, antisocial, a person who intentionally distanced himself from his own family. Having committed such deeds, this quote emphasizes his loneliness, the fact that he has no one to turn to for consolation and support, and his great sense of insecurity, which points out how he constantly looks over his back, feeling ashamed, guilty, and fearful.

The third narrative frame contains the Monster's voice. The overall focus of this frame revolves around isolation, rejection, and confusion. The Monster expresses his sense of abandonment and hopelessness by saying, "I was dependent on none and related to none. The path of my departure was free, and there was none to lament my annihilation. My person was hideous and my stature gigantic. What did this mean? Who was I?" (Coleridge 1970, 1. 152). The idea of abandonment reflects the idea that the creator abandoned his creation, and thus relates to moments where the Mariner felt so desperate that he believes God had left him: "Alone on a wide wide sea: So lonely 'twas, that God himself scarce seemed there to be." (Coleridge 1970, 11. 597-600) To be without hope is equal to being outside of God's grace. Both the Mariner and the Monster feel abandoned by their creators. 
At the thematic level of the novel's organization, we've encountered isolation in the first narrative frame, fear and transgression in the second, and abandonment and rejection in the third. The same could be said for Mariner, who goes through a similar journey to the monster. Ultimately, both Shelley and Coleridge use the theme of damnation as a major undertone to their stories and raise the question of whether there exists a redemption or not; one way through which they did so was through the use of water. There is an inner reference to the Mariner by the Monster: "I had already been out many hours, and felt the tournament of a burning thirst" (Shelley 1818, 211). Compare this to a complaint by the Mariner: "Water, water everywhere, nor any drop to drink" (Coleridge 1970, 1.121-122). The quote alludes to Satan's lair again, the ice-filled level of Hell; this implies the eternal damnation of constantly feeling thirsty. By stating that the Monster and Mariner both feel deprived of water, receiving the same punishment as the most evil form of existence, the authors affirm the theme of damnation.

Not only does the Mariner share traits with the Monster, he also resembles the character of Victor. Both of their own natures are not transparent to them. The act of denying God's grace could be traced all the way back to Adam and Eve, whose motivations were given by the snake morphed by Satan. In contrast, however, the motivations of the Mariner are ambiguous. The Albatross's last words were a question: "-Why look'st thou so?" (Coleridge 1970, 1. 81) signifying what the situation symbolizes is perplexing. The question brings out the image that the Albatross is baffled by the sinister, violent, and homicidal look on the Mariner's face, it doesn't understand. At this moment, the reader is positioned in the place of an active interpreter because the absence of a direct description of the Mariner's face raises the questions of his intentions and character. The killing of the albatross indicates the Mariner's need to carve the boundaries of the known and unknown, and establishing certainty. The albatross is a divine benefaction but also a undeniable reminder of a transcendently ordered universe: it's that order which the Mariner is unconsciously rebelling against. This trait in the Mariner was referenced by Shelley for her character Victor, both of whom denied a higher order as Adam and Eve did. Frankenstein violates the rules of nature and assumes the position of God. When talking about his and Elizabeth's differences in interests and disposition, Victor says, "The world was to me a secret which I desired to divine" (Shelley 1818, 31). The diction here both describes his urge to solve the secret riddles of natural science, but also ironically demonstrates that he's usurping the role of God. But instead of caring for his creation, he was frightened and scared. He crossed the boundary of the unknown and was too scared to take up the responsibility of its consequences. However, the reason behind his running away and the abandonment of the monster is unclear, just like the Mariner's motivation for killing the albatross.

\section{The Wandering Jew}

The 'Ancient Mariner' is inflected in Frankenstein structurally and thematically. The structural inflection tracks the tripartite narrative framing, the thematic inflection looks on the way the Mariner draws on the archetypes of the Wandering Jew and of Cain.

The Wandering Jew (Brunel 1995, 826-834) is an archetypal figure reflecting themes of isolation, ostracism from society, and the compulsion to retell a tragic story of transgression. It shares nearly identical elements with 'The Ancient Mariner', and it acts as a trope for the narrative process itself in Frankenstein. The Wandering Jew was believed by Christians to be someone who indirectly killed God by denying and slapping Christ. The same crime could be held against the Mariner, who uses a crossbow (a Christian motif) to kill the Albatross, forming a literal second crucifixion of Christ.

\section{Cain}

The second archetype Coleridge uses is Cain, [10]from the Book of Genesis (Gen. 4:1-16). As the first flesh and blood of Adam and Eve, he is responsible for the murder of Abel, which is recorded as the first murder, a result of fraternal rivalry. After committing the murder, Cain was condemned by God to wander the earth alone. 'Wanderings of Cain' was written by Coleridge in 1797 and served as the precursor of 'The Ancient Mariner' and a beginning of his interest in the origin of evil (Beyer 1956). 
Consequently, the themes of isolation, transgression, and damnation flows through the 'Ancient Mariner' as they do for the Cain-Abel story. Both characters, through their actions, degraded themselves to the state of slaves, constantly rejected, passives beings at the mercy of others. To protect Cain from the wilderness which he fears, God left a mark on Cain to protect him from harm, which is similar to the marks or branding on slaves by their owners, who used the mark to identify and recapture runaway slaves and help the locals easily recognize their low identities. For the Mariner, he was condemned to have the dead Albatross hang around his neck, and the image could be related to that of a salve in chains. For both figures, people could immediately recognize them by their signifying motifs - the mark and the albatross, and as a result recognize their sins.

Cain is also filtered into Frankenstein: he resembles qualities of Victor, who also suffers the transgressing of moral limits and punishment thereafter. Both Cain and Victor tread into areas that were unexplored before and lie about their actions. Cain lied to God when being questioned on Abel's whereabouts, "And he said, I know not: Am I my brother's keeper? This parallels Frankenstein's justification of himself: his abandonment of the monster is almost implying, am I my creature's keeper? In the case of Cain, God confronted him: "What hast thou done? the voice of thy brother's blood crieth unto me from the ground."(Gen 4:9-10); as for Frankenstein, he felt disconnected from his friends because of his sin and the fact that he's keeping the existence of the Monster a secret: "I saw plainly that he was surprised, but he never attempted to draw my secret from me; and although I loved him with a mixture of affection and reverence that knew no bounds, yet I could never persuade myself to confide to him that event which was so often present to my recollection" (Shelley 1818, 73). Here, Frankenstein expresses his inability to confess to his friend Henry Clerval, who is someone focused on morals, the complete opposite character of Frankenstein. Frankenstein is always trapped in his own consciousness of his sin; he cannot gain relief by confessing, and that denies him any capacity for brotherhood and companionship.

\section{The Ancient Mariner's Moral}

The story startes with isolation, fear, and being overwhelmed by the wild and unpredictable Arctic. The act of transgression is the Mariner's shooting of the albatross; for that, he receives punishment from the God, as well as eternal damnation - a compulsion to tell stories to those whom he deems necessary to listen. The damnation is qualified by a stoical "wisdom", meaning the stoical acceptance of suffering without any transcendental redemption, thus it merely signals the acceptance of his exclusion from God's mercy and grace. Overall, 'The Ancient Mariner' revolves on two mysteries. One, why did the Mariner kill the albatross; two, is he eternally damned by his action or does he receive redemption?

The Mariner's story is one of rejection and alienation, but at the same time, it speaks to us as readers, as it captivates us with its language, plots, and myths. At the inner level, the poem showcases the possibility of hope for the guest, who is listening and taking away the cautionary moral. At the outer level, the frame of the discourse between Coleridge's persona and us, the communication established between the writer and reader is what justified the use of archetypes. Because the universal application of archetypes in myths builds the relationship between writer and reader, giving the readers elements they could empathize with, and allows them to better comprehend the villains' motives, sins, and regrets. The Mariner himself does not receive redemption, he's always suspended in a constant state of agony and isolation, "and till my ghastly tale is told, /This heart within me burns" (Coleridge 1970, 11. 584-585), which makes the only way he could receive a redemption is if we listen. Recognizing an archetype in literature becomes our moral obligation, as if a plea from the archetype.

\section{Frankenstein's Moral}

The moral transformation in Frankenstein's own self-conception-from brave scientific experimenter, exceeding the bounds of knowledge triumphantly, to fearful soul repelled by his own horrifying creation - is most vividly communicated by the bodily imagery and the symbol of his 'heart'. When Victor flees from his monster, he says: "my heart palpitated in the sickness of fear," (Shelley 1818, 61) both contrasts with his own description of the "beautiful season" wherein his "heart and soul" were 
engaged in the miraculous pursuit of creating life from inert matter, and also, in its emotive register of dread, ironically parallels the way Frankenstein described the "filth", "profanity" and "loathing" of the "materials" he collected from the "charnel houses", "dissecting rooms and slaughter-house" (Shelley 1818 , 55) Frankenstein, in using the language of dread to describe his own reaction to his creation, ironically associates himself with the body of his monster itself, thus setting up the monster as his own double. This technique of doubling unconsciously generates a moral conscience in Frankenstein, which splits his self-conception between positive (triumphant scientist) and negative poles (moral transgressor; in a word, a monster).

The moment Victor succeeds scientifically is the very moment he fails morally. He becomes his own monster. The fact that Victor directly quotes 'The Ancient Mariner', demonstrates that, at the very moment when his moral conscience is aroused, he recalls an archetypal poetic figure who is renowned for his tortured moral conscience. Thus a vivid parallel is created. Existential isolation occasioned by the arousal of his moral conscience. Not a self-imposed isolation from society; rather, he experiences his moral conscience as an external force which is pursuing him as prey, as an object of admonishment and eventually punishment.

\section{Conclusion}

Archetypes are such a powerful technique for creating both an inter-textual universe in the world of novel, adding depth to characters by allusions to universal things. But perhaps most powerfully, archetypes in literature create inter-generational links between readers and writers, demonstrating how universal stories and symbols must be interpreted and inflected by the particular interests, concerns, and deepest problems of every generation.

\section{References}

Alighieri, Dante. 1935. The Divine Comedy of Dante Alighieri: Inferno, Purgatory, Paradise. The Union Library Association.

Beyer, Werner. 1965. "The Background of Coleridge's 'Cain', Precursor of 'The Ancient Mariner'." Notes and Queries, vol. 3, no.1, 32-24.

Botting, Fred. 1990. “Frankenstein's French Revolutions.” Literature and History, vol. 1, no. 2, 22-41.

Brunel, Pierre (ed.). 1995. Companion to Literary Myths, Heroes and Archetypes. Routledge.

Coleridge, Samuel Taylor. 1970. The Rime of the Ancient Mariner. 1798, Dover Publications.

Holmes, Richard. 2016. "The Science that Fed Frankenstein.” Nature, vol. 535, 490-492.

Milton, John. 2004. Paradise Lost. Edited by David Loewenstein. Cambridge University Press.

Shelley, Mary. 2012. Frankenstein; or the Modern Prometheus 1818. W.W. Norton. 